\title{
First fossil harvestmen (Arachnida: Opiliones) from Spain and notes on the fossil record of Opiliones
}

\author{
Lorena Palencia, Enrique Peñalver, Carlos E. Prieto, \\ and Francisco José Poyato-Ariza
}

\begin{abstract}
The first two harvestmen (Arachnida: Opiliones) from the fossil record of Spain are reported herein. The first one is an imperfect specimen from the Early Cretaceous (Barremian) laminated limestones of Las Hoyas (Province of Cuenca). The second one is a complete, finely-preserved specimen from the Early Miocene (Burdigalian) lacustrine oil-shales of the Rubielos de Mora Basin (Province of Teruel). Both sites are Konservat-Lagerstätten that have a rich fossil record of numerous plant and animal groups. The Barremian specimen is considered here as Opiliones indet. because the poor state of preservation does not allow identification of diagnostic characters at subordinal level. The Miocene specimen is a new species of the extant genus Cosmobunus (Sclerosomatidae), C. sagani nov. sp., diagnosed by its unique set of cuticle sculpturing within the genus. A review of the scarce fossil record of the group and some general taphonomic factors that may explain such scarcity are provided as well.
\end{abstract}

Lorena Palencia. Universidad de Alcalá de Henares, Spain. Iorena.palencia@edu.uah.es Enrique Peñalver. Instituto Geológico y Minero de España (Museo Geominero), C/ Cirilo Amorós, 42, E46004 Valencia. Spain. e.penalver@igme.es

Carlos E. Prieto. Departamento de Zoología y Biología Celular Animal, Facultad de Ciencia y Tecnología, Universidad del País Vasco/EHU, Bilbao, Spain. carlos.prieto@ehu.eus

Francisco José Poyato-Ariza. Departamento de Biología. Universidad Autónoma de Madrid. Spain. francisco.poyato@uam.es

Keywords: Arachnida; new species; compression fossils; Early Cretaceous; Early Miocene; Spain

Submission: 2 February 2018 Acceptance: 17 December 2018

http://zoobank.org/0383B140-3EC0-4E45-904E-6ECBF9DFF202

Palencia, Lorena, Peñalver, Enrique, Prieto, Carlos E., and Poyato-Ariza, Francisco José. 2019. First fossil harvestmen (Arachnida: Opiliones) from Spain and notes on the fossil record of Opiliones. Palaeontologia Electronica 22.1.5A 1-18. https://doi.org/10.26879/ 855

palaeo-electronica.org/content/2019/2393-new-fossil-harvestmen

Copyright: February 2019 Paleontological Society.

This is an open access article distributed under the terms of the Creative Commons Attribution License, which permits unrestricted use, distribution, and reproduction in any medium, provided the original author and source are credited.

creativecommons.org/licenses/by/4.0/ 


\section{INTRODUCTION}

The extant Order Opiliones Sundevall, 1833 constitutes about 50 families and a total of ca. 6,500 species (Kury, 2017); it is the third richest group of Arachnida after Acari and Araneae. In contrast, its fossil record is very scarce. The recent distribution of the group comprises all continents except Antarctica, mostly in the less-anthropized areas of temperate and tropical climates (Giribet and Sharma, 2015).

Most Opiliones are predators, but some species are scavengers, omnivores, or coprophages (Giribet and Sharma, 2015). The anatomy of this group is described in detail by Shultz and Pinto-daRocha (2007). Beside liquid food, the Opiliones can feed on small particles, unlike all other arachnids (Ruppert et al., 2004). Most harvestmen can move quickly, even climb. As a defense, some species spray intruders with substances generated in the repugnatory glands; other species mix the repugnant fluid with regurgitated fluid from the digestive system and introduce it into the predator oral cavity (Ruppert et al., 2004). Another method of defense against predation is the self-amputation of the legs, but in the case of the Opiliones the legs cannot regenerate once lost (Ruppert et al., 2004). Concerning reproduction, Opiliones, together with some Acari groups, are the only arachnids that engage in direct copulation.

The present paper describes two Spanish specimens of Opiliones, both recorded as compression fossils. The first one, Cretaceous in age, is considered Opiliones indet. The second one, Miocene in age, is described as a new species of the family Sclerosomatidae. Some general taphonomic factors are considered in order to try to account for the poor fossil record of this rich arachnid group.

\section{GEOLOGIC SETTING}

The Early Cretaceous (early Barremian) locality of Las Hoyas (La Cierva, Province of Cuenca) is a very rich fossiliferous site located in the Serranía de Cuenca, east-central Spain. Initially interpreted as lacustrine deposits, it has been recently reinterpreted as a tropical wetland (see FregenalMartínez and Meléndez, 2016, for a history of the environmental reconstruction of the locality, and Buscalioni et al., 2016, for a synthesis of the interpretation of the paleoecosystem). Its impressive fossil record includes representatives of most of the plant and animal groups forming the original ecosystem. Arthropods are represented by Arachnida (Selden, 2016), Diplopoda (Selden and Shear,
2016), Ostracoda (Rodríguez-Lázaro, 2016), Spelaeogriphacea (Jaume et al., 2016), Decapoda (Garassino, 2016), and a huge diversity of insects from 13 orders and 40 families, both terrestrial and aquatic (see Delclòs and Soriano, 2016, and references therein).

The Early Miocene (early Burdigalian) deposits of the Rubielos de Mora Basin (Province of Teruel) in eastern Spain are rich in fossil insects and arachnids, among other animal groups. This basin, limited by normal faults, is located in the south-eastern Iberian Chain. Fossil arthropod specimens appear in oilshales formed in a stratified (meromictic) lake. Bioturbation has never been observed in this locality. Four important outcrops have provided the paleoentomological record of this basin. Among them, the "Río Rubielos" outcrop, east of Rubielos de Mora village, is the richest in fossil arthropods (Montoya et al., 1996; Anadón et al., 2003; Peñalver, 1998, 2002, 2007). Several new insect species have been described from Rubielos de Mora Basin, e.g., the aphid Greenideoida turolensis, the halictid bee $\mathrm{Hal}-$ ictus petrefactus, and the megaspilid wasp Conostigmus lazaros (Wegierek and Peñalver, 2002; Engel and Peñalver, 2006; Peñalver and Engel, 2006, respectively). In spite of its rich arachnid record (Araneae and one harvestman), new species of this group have not been described from any of the four outcrops prior to the present paper.

The taphonomic features observed at the Las Hoyas site (Briggs et al., 2016; Poyato-Ariza and Buscalioni, 2016) and the diverse localities in the Rubielos de Mora Basin (Peñalver and Seilacher, 1995) are those characterizing Konservat-Lagerstätten. Remarkable taphonomic features of the fossil arthropods from both Las Hoyas and Rubielos de Mora include: i) high degree of articulation in most specimens, ii) good preservation of some very delicate external structures, such as microscopic cuticle sculpturation, iii) preservation of internal organs (spermathecae, gut content), and iv) preservation of body and wing color patterns.

\section{MATERIAL AND METHODS}

The specimen from the Cretaceous limestones of Las Hoyas is housed at the Museo de Paleontología de Castilla-La Mancha (MUPA) in Cuenca, Spain, under label LH-29969, preserved as part and counterpart. Drawings were done by using a camera lucida attached to a Nikon SMZ-10 stereomicroscope, hand-inked, and digitized. Plates were prepared by using the software Adobe Photoshop. 
The Miocene specimen is housed at the Rubielos de Mora collection of the Museo de Ciencias Naturales de Valencia in Spain under the label MPV-2417-RM. The specimen is preserved as a carbonaceous film with cracks due to dehydration after exposure and preparation; it was locally treated with a hardening agent (Peñalver, 1998, 2002). The specimen was studied and photographed under ethanol in order to enhance the diverse anatomical structures.

Line drawings were done with a camera lucida SZX-DA attached to an Olympus SZX9 stereomicroscope. Photographs in dorsal and lateral view of an extant specimen of Cosmobunus granarius (Lucas, 1846) were taken with a digital camera Canon EOS 650D using the software "Macrofotografía", version 1.1.0.5, for comparison. The software created composite photographs by integrating sequential images obtained at different focal planes. Microphotography of some anatomical details of extant specimens was made with a digital camera MOTIC 2000 (5Mpx) attached to a Nikon SMZ 1500 stereomicroscope. Microphotography of the second fossil specimen was made with a digital camera Olympus Camedia MODEL N.C5050 ZOOM attached to an Olympus SZX9 stereomicroscope and a digital camera ColorView Illu Soft Imaging System attached to an Olympus BX51 microscope. Specimens of three extant species of the subfamily Leiobuninae (Sclerosomatidae) were used for comparison with the Miocene specimen: Cosmobunus granarius, Leiobunum defectivum Rambla, 1959 and L. rotundum (Latreille, 1798), all collected by one of the authors (C.E.P.) and housed at the Universidad del País Vasco collection.

The anatomical descriptions focus on the external morphology of body and appendages (Prieto and Fernández, 2007). We follow Pinto-daRocha and Giribet (2007) for the taxonomic assessment of the specimens, considering the limitation of those characters preserved in the fossils, and Sharma and Giribet (2014) for the phylogeny of Opiliones.

All measurements are in $\mathrm{mm}$ unless otherwise stated. For pedipalps and legs, if not indicated, each measurement is the average of the measurements from the right and left appendages unless otherwise indicated as the only available measurement.

\section{SYSTEMATIC PALEONTOLOGY}

Class ARACHNIDA Lamarck, 1801

Order OPILIONES Sundevall, 1833

\section{Suborder indet.}

Figure 1

Description (specimen LH-29969). Typical harvestman habitus, compact body and slender legs. The eight legs appear radiating closely together. Leg lengths are indicated on Figure 1. Leg articulations only are clear in three locations (Figure 1.2).

Taphonomy. The body of this specimen is poorly preserved, lacking any detail; chelicera and pedipalps are not observable. Anatomical orientation is uncertain due to the poor preservation of the body, which was collapsed in a small area during fossilization. Legs appear radiating very close, nearly together, probably due to this collapsing of the body.

Remarks. The habitus is typical of harvestmen, especially that of the suborders Laniatores and Eupnoi. However, no distinctive morphological details such as pedipalps and tarsal claws of legs are preserved. Although most long-legged harvestmen show a typical I-IV leg length pattern (short,
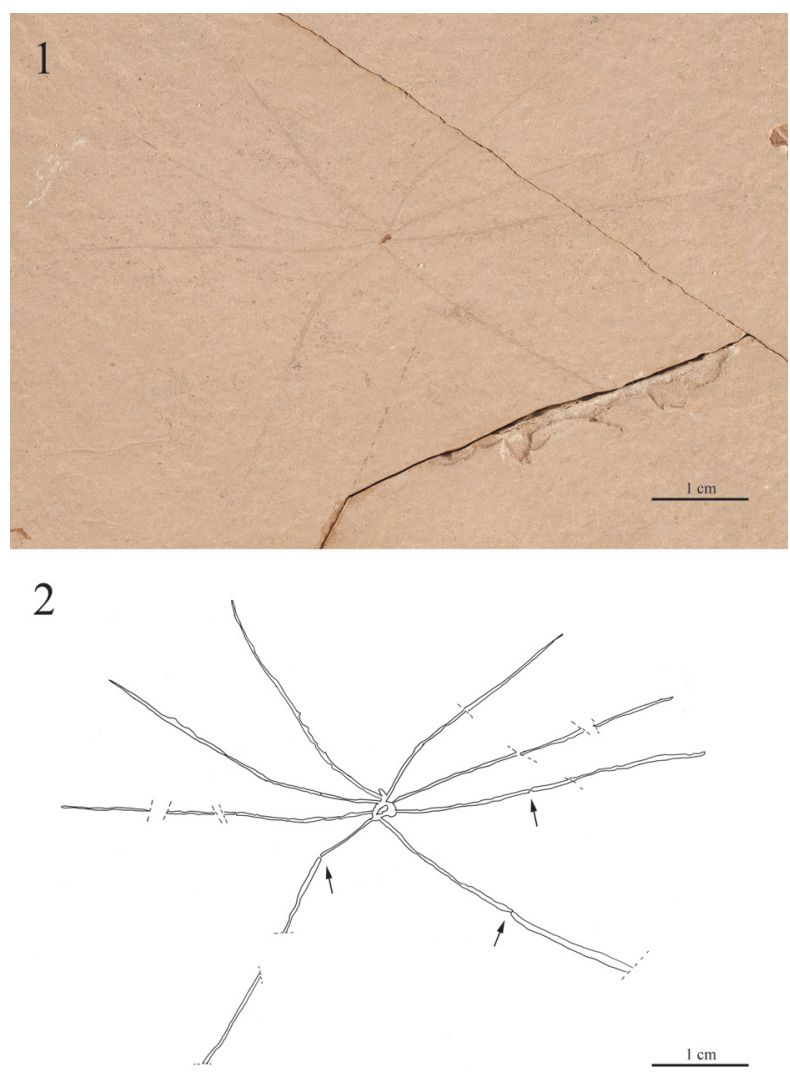

FIGURE 1. Cretaceous harvestman of uncertain suborder, LH-29969, from Las Hoyas. 1, Photograph of LH29969. 2, Camera lucida drawing of LH-29969. Arrows indicate the detected leg articulations. 
longest, short, long), this feature is not discernible in the specimen. A few articulations in the legs can, nonetheless, be observed. The radiation and habitus of the legs are consistent with those of harvestmen. The habitus and the thin legs are similar to those of the family Pholcidae, Order Araneae. This family shows a body clearly divided into two tagmata, but the body of the fossil specimen, in spite of its poor preservation, seems to present fused tagmata ("compact body"). In spite of its unsatisfactory preservation, this specimen is worth reporting because of the Mesozoic fossil record of harvestmen is remarkably scarce.

Suborder EUPNOI Hansen and Sørensen, 1904

Family SCLEROSOMATIDAE Simon, 1879

Genus COSMOBUNUS Simon, 1879

Type species (by monotypy). Phalangium granarium Lucas, 1846.

Cosmobunus sagani nov. sp.

Figures 2-5

zoobank.org/B970A094-E9E0-4E57-BA9F-978513452047

Diagnosis. Fossil species of Cosmobunus with the following unique combination of features: pedipalps with smooth tarsal claw and rows of laterodistal granules in the tibiotarsal articulation, smooth ocularium, and trilobate coxal denticles.

Material. Holotype (MPV-2417-RM), adult individual, most likely a male. Specimen present in a large slab of oil-shale measuring $37 \times 20 \times 1 \mathrm{~cm}$. Specimen appears in dorso-ventral position, slightly lateral (tilted towards the right), nearly complete and well preserved, having lost only the main part of the right leg I; the distal part of the left leg IV is displaced close to the body. The same slab also contains a few indeterminate plant remains. Type specimen housed at the Museo de Ciencias Naturales de Valencia, Valencia, Spain.

Derivation of name. In memory of Carl Edward Sagan (1934-1996), creator of the award-winning television series Cosmos: A Personal Voyage, for his popularization of science that stimulated generations of school children and university students.

Type horizon. Lacustrine oil-shales from the Early Miocene (early Burdigalian) of Rubielos de Mora Basin (Iberian Chain).

Type locality. "Río Rubielos" outcrop, Rubielos de Mora municipality, Province of Teruel, Spain.

Description. Body length: 5.3; body width: 4.1 (artefactual due to the lateral shift, estimated 3).

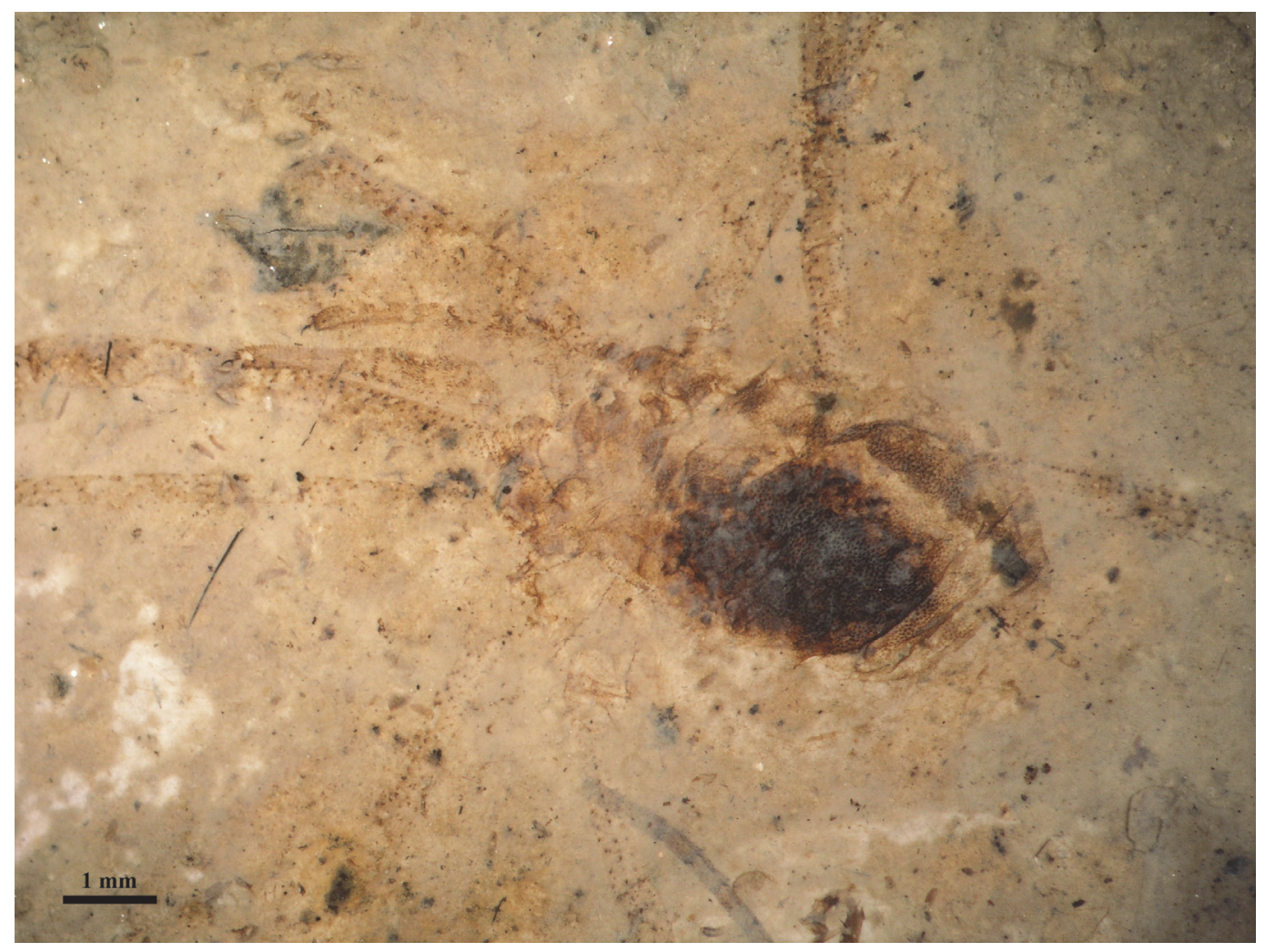

FIGURE 2. Photomicrograph under ethanol of Cosmobunus sagani nov. sp. (Sclerosomatidae), from the Miocene of Rubielos de Mora Basin. Holotype (MPV-2417-RM), most likely a male. 

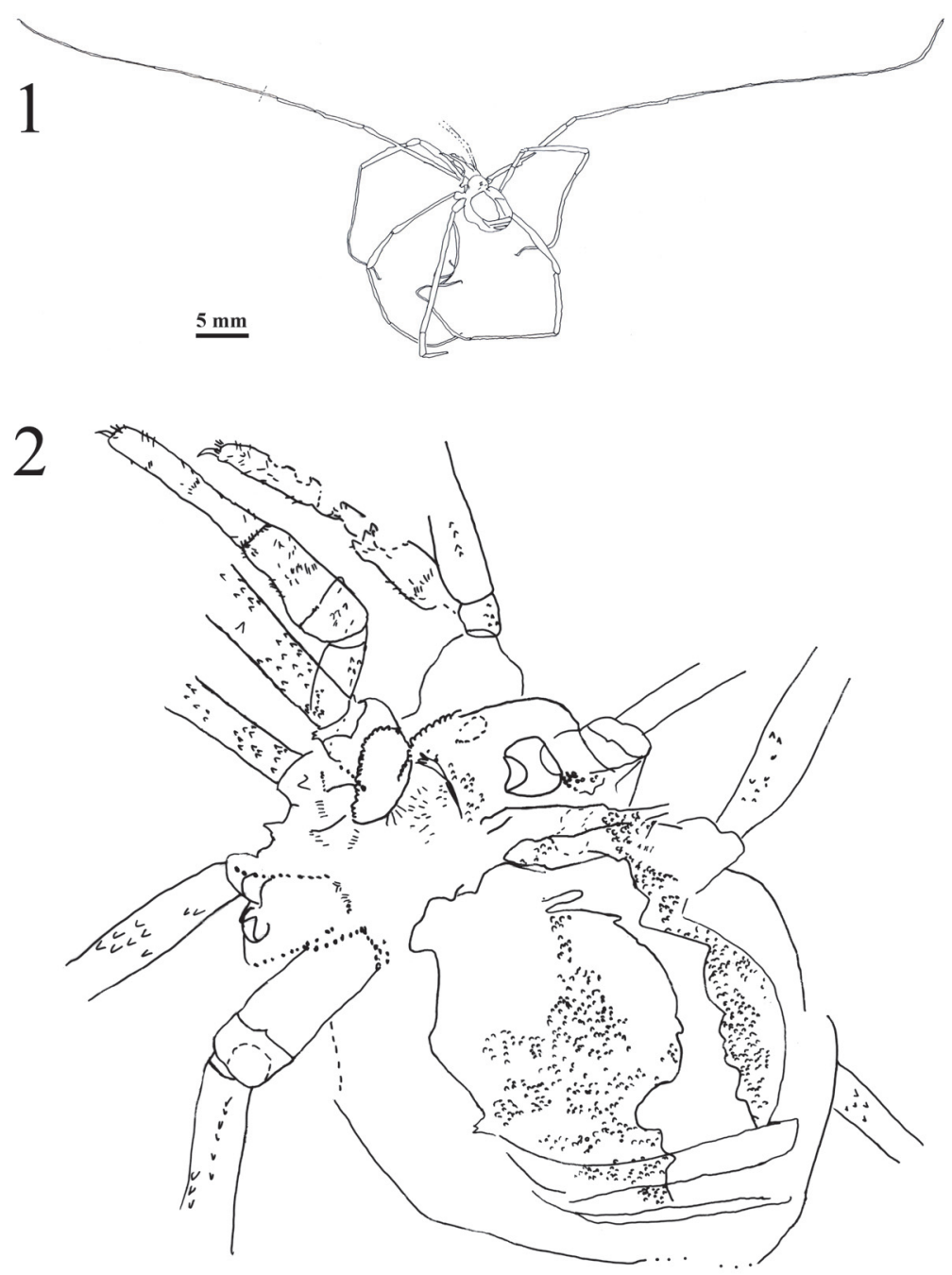

$1 \mathrm{~mm}$

FIGURE 3. Cosmobunus sagani nov. sp. (Sclerosomatidae), holotype (MPV-2417-RM), most likely a male. 1, Camera lucida drawing of the habitus. 2, Detail of the body.

Prosoma: Carapace length: 1.2. Cuticle with granulate ornamentation. A postocular line suggests the presence of a metapeltidium. Supracheliceral lamina not visible. Ozopores not discernible. Ocularium globular (Figure 4.2), as long as wide $(0.5 \mathrm{x}$ $0.5)$, distant from frontal edge, smooth, without granules.

Opistosoma: Anterior edge of scutum smooth. Scutum with conspicuous granulate ornamentation (Figure 4.6); granules roundish, $40 \mu \mathrm{m}$ in diameter, tightly arranged together. Color pattern: dark lateral regions and a lighter longitudinal dorsal band; the left region appears considerably wider and darker. Three free tergites granulate as the scutum.
Ventral: Posterior coxapophysis preserved, with distal pilosity, observable by transparency.

Appendages: Chelicera not visible, hidden beneath body. Right pedipalp poorly preserved (Figure 4.1). Left trochanter and basal part of femur hidden beneath body. Distal part of femur with some acute granules. Patella wide, with acute granules. Tibia longer and higher than patella, covered by trichomes, scattered long sensillae, and sharp granules; distal end lined with sharp granules (Figure 4.4). Tarsus covered with stiff sensillae and small trichomes; medioventral area darker. Tarsal claw smooth. Measurements: Patella (left) 0.4, tibia (left) 0.8 , tarsus 1.5 . 

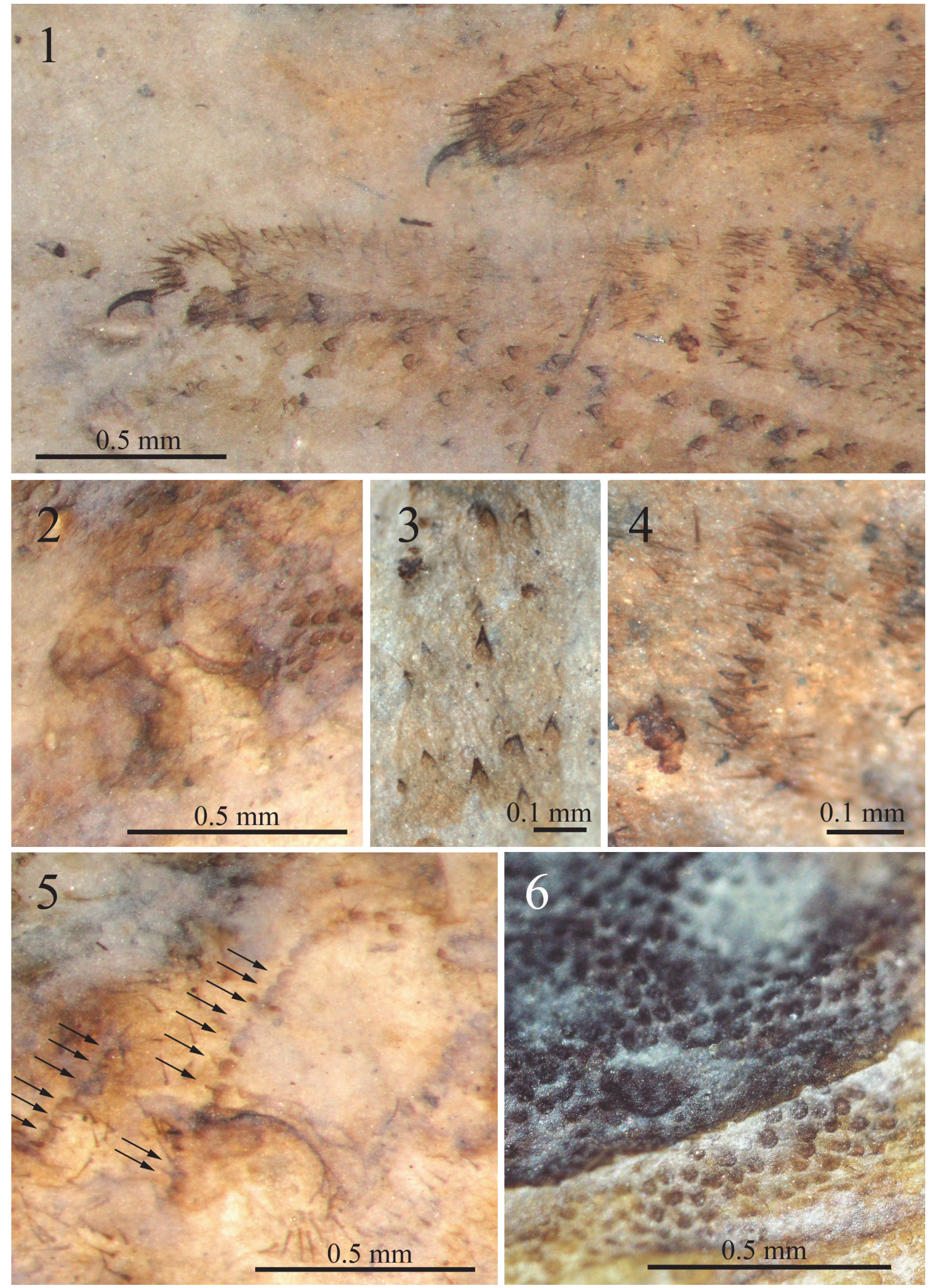

FIGURE 4. Microphotographs of some anatomical details of Cosmobunus sagani nov. sp. (Sclerosomatidae), holotype (MPV-2417-RM), most likely a male, taken under ethanol. 1, pedipalps. 2, smooth ocularium. 3, granules on leg I. 4, row of laterodistal granules in the tibiotarsal articulation of the pedipalp. $\mathbf{5}$, rows of trilobate denticles on two coxae (arrows point some of the denticles). 6, cuticular granulate ornamentation on the opistosoma. Image 3 made with some pictures taken at successive focal planes, as explained in the text. 


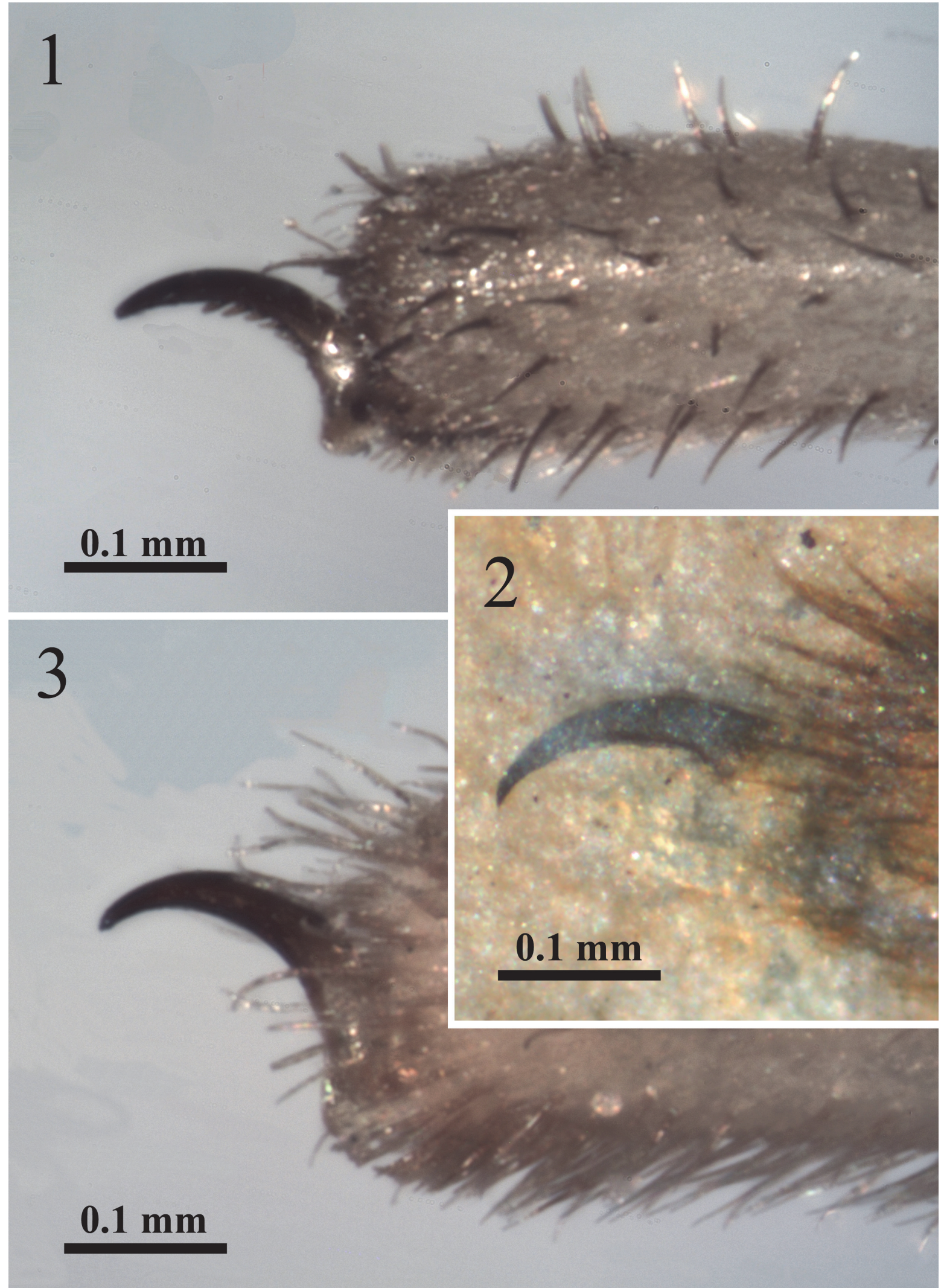

FIGURE 5. Microphotographs of the pedipalpal tarsal claw. 1, Extant Leiobunum rotundum (pectinated claw). 2-3, Fossil Cosmobunus sagani nov. sp. and extant Cosmobunus granarius (both with smooth claw). All to the same scale. 
Leg measurements: Leg I: Length; Femur 5.3, Patella 1.3; Tibia 4.5; Metatarsus 2.3; Tarsus 9.8. Leg II: Length; Femur (left) 9.1, Patella (left) 1.4; Tibia 8.6; Metatarsus (left) 8.6; Tarsus (right) 19.1. Leg III: Length; Femur (left) 5.3, Patella (right) 1.4; Tibia (right) 4.4; Metatarsus 4.9; Tarsus (left) 7.9. Leg IV: Length; Femur 6.5, Patella (left) 1.6; Tibia (right) 5.6; Metatarsus (right) 8.4; Tarsus (right) 10.2 .

Coxa I: Separated from prosoma, slightly displaced, and connected to leg I. At least anterior rows of coxal denticles present; coxal denticles small (9-10 per $0.5 \mathrm{~mm}$ ) and weak, slightly trilobate. Trochanter not visible. Femur with conical denticles (Figure 4.3). Patella presents the least amount of small denticles. Tibia considerably wide; microtrichiae present. Tarsus multisegmented, with ventrodistal spines. Tarsal claw simple, curved and smooth.

Remarks. The presence/absence of protuberant ozophores bearing ozopores and the morphology of the tarsal claws of legs III-IV are important characters for the subordinal assessment of Opiliones (Pinto-da-Rocha and Giribet, 2007). These features allow the exclusion of Cyphophthalmi (having ozophores, lacking median eyes) and Laniatores (having ramified or two tarsal claws on legs III-IV, and raptorial pedipalps with robust spines), but these characters are insufficient by themselves. Both Eupnoi and Dyspnoi suborders, grouped together in Palpatores, have single simple tarsal claws and graceful antenniform pedipalps. In the absence of cheliceral features (shape and size of chelal teeth) or genitalic features, the relative length of pedipalpal tibia and tarsus is the most reliable character.

A tarsus longer than the tibia (1.5 vs. 0.8 in the Rubielos de Mora specimen) in the pedipalp is typical of most taxa of the suborder Eupnoi (except Protolophidae), although this difference may not be considered significant due to the deformations that could occur during lithostatic compression, and also considering that the specimen rested in the lake bottom substrate tilted laterally. In addition, the pedipalp tarsal claw is lacking or rudimentary in Dyspnoi, being a short peg at most, but it is well developed in Eupnoi.

The suborder Eupnoi comprises two superfamilies, the monotypic Caddoidea and Phalangioidea, with four families (Kury, 2017; Fernández et al., 2017). Only two living families are found in the Western Palearctic Region. However, a member of the Caddidae, currently restricted to North America, Chile, Japan, Australia, New Zealand, and
South Africa has been reported from Baltic and Bitterfeld ambers (Dunlop and Mitov, 2009). Therefore, the other taxa with current North American distributions (Protolophidae) cannot be excluded a priori in Europe in the past. However, the monotypic Protolophidae present very dimorphic pedipalps (long patellar apophysis in females, huge curved tibia and shorter tarsus in males) and short legs (Cokendolpher in Pinto-da-Rocha and Giribet, 2007). In turn, the monotypic Caddidae has tiny bodies with huge ocularium and eyes, and spiny pedipalps (Dunlop and Mitov, 2009). Therefore, both families can be discarded.

A relevant distinctive anatomical feature between Sclerosomatidae and Phalangiidae is the tarsal claw of the pedipalps, which is normally pectinate in the former and smooth in the latter, although with exceptions in both families (Pinto-daRocha and Giribet, 2007). The fossil specimen presents smooth claws, but other characters suggest an affiliation to Sclerosomatidae, especially the presence of rows of coxal denticles and the absence of rows of denticles or setae along the edges of the femur and the tibia.

Within Sclerosomatidae, four subfamilies are currently regarded: the Pantropical Gagrellinae, the Holarctic Leiobuninae, and the Palearctic Gyinae and Sclerosomatinae (Pinto-da-Rocha and Giribet, 2007). The Gyinae, lacking coxal denticle rows, must be transferred to the Phalangiidae, as shown by the molecular analyses of Hedin et al. (2012) and Fernández et al. (2017). Among the other three subfamilies, the Sclerosomatinae present sclerotized bodies with a tuberculate opisthosoma and short legs, so it can be excluded. This leaves the tropical Asian/American Gagrellinae and the Holarctic Leiobuninae as remaining possibilities. Distinction between them is complex; most Gagrellinae have femoral nodules (at least one in femur II), but, other than this, only biogeographical considerations can be used, and, as a consequence, their taxonomic validity has been questioned (Martens, 1987; Hedin et al., 2012). The presence of leiobunines, with absence of gagrellines, in the European amber fossil record (Dunlop, 2006; Dunlop and Mitov, 2009) could be due to an ancient vicariant event, thus allowing assessment of the Rubielos de Mora specimen to the Leiobuninae on the basis of the presence of rows of coxal denticles. The European Leiobuninae are formed by three genera. Nelima Roewer, 1910, is a genus based only in the absence of coxal denticles, which could be due to heterochronic processes (Hedin et al., 2012). This leaves 
Leiobunum Koch, 1839 and Cosmobunus as the only possibilities.

The genus Leiobunum currently includes more than 100 species from the Holarctic region (about twenty in Europe), but it has been shown to be polyphyletic (Hedin et al., 2012). In turn, Cosmobunus is a monotypic genus (spurious species removed) geographically restricted to Iberia and Morocco. The diagnostic feature between both genera is the absence of pectination on the tarsal claw of the pedipalp in Cosmobunus, a feature that fortunately can be checked in both appendages of the fossil specimen.

A smooth tarsal claw in the pedipalp and leg coxae without denticle rows were the characters used by Banks (1901) to erect the Leptobuninae for some North American genera, but Roewer (1910) dismissed the second character to include Cosmobunus and Protolophus Banks, 1893. The subfamily was then considered polyphyletic and, therefore, modified by Cokendolpher (1985), who transferred Cosmobunus (after removing spurious North American species) and the North American Leuronychus Banks, 1900 to the Leiobuninae, and the remaining genera to other subfamilies of Phalangioidea. The only paper devoted to Cosmobunus granarius was that of Rambla (1970); she redescribed the genus, considered Cosmobunus unicolor Roewer, 1910 as senior synonym of Cosmobunus unifasciatus Roewer, 1923, outlined the geographical distribution of the genus according to many new records and added biological information.

Since the presence of coxal denticles is an adult feature, the issue about the sex of the studied individual still remains. Sexual dimorphism in Leiobuninae is reduced to a slightly longer leg length and hardiness in males and a broader opisthosoma in females, occasionally with dimorphic color pattern (Tourinho in Pinto-da-Rocha and Giribet, 2007). However, in absence of genital features, sex can be inferred by comparison only; Rambla (1970) stated that in Cosmobunus granarius both sexes are alike. A secondary sexual character in Phalangioidea is the presence of a ventromesal row/belt of microgranules along the pedipalpal tarsus (Pinto-da-Rocha and Giribet, 2007). This feature seems to be present in the studied specimen as a darker strip in the corresponding area, thus being a male.

The legs of the fossil specimen are notably shorter than the measurements provided by Roewer (1923: 42, 64, 40, 55) and Rambla (1970: $45,78,46,60)$, for males of Cosmobunus granar- ius, reaching $50-60 \%$ (up to $73 \%$ for leg II) of the recorded leg lengths of the extant species. However, there is no information about its individual variability to consider the significance of such difference. As shown by Rambla (1970), C. granarius has marginal denticle rows in all leg coxae except for the back margin of the coxa III. This character is shown by some European Leiobunum, although there are species with a reduced dotation of the coxal rows (Prieto and Fernández, 2007). Only three forward denticle rows of the fossil specimen are exposed, so that coxal configuration cannot be determined. Coxal denticles of C. granarius are usually trilobate (Rambla, 1970); same goes for many species of Leiobunum, some of them with a characteristic shape within the broad variability (Prieto and Fernández, 2007). Although the coxal denticles of the fossil specimen are clearly trilobate, they are smaller and weaker than those of $C$. granarius (6 denticles per $0.5 \mathrm{~mm}$ ) (Figure 6.3-4).

The ornamentation of the dorsal surface of the fossil specimen consists of rounded granules 40 $\mu \mathrm{m}$ in diameter and densely packed. This is similar to that of Cosmobunus granarius. Moreover, the color pattern is congruent with the dorsal pattern of C. granarius, a light, broad median band flanked by lateral dark areas (Figure 6.1).

The ocularium of the fossil specimen is smooth, as in Leiobunum and most Sclerosomatidae genera. In the specimens of Cosmobunus granarius used for comparison, a great deal of variability has been observed in the sclerotization of the rows of granules of the ocularium; that is, these rows of granules can be more conspicuous or less conspicuous. Therefore, the body of the fossil specimen presents a dense granulate ornamentation, trilobate coxal denticles, and a body coloration similar to those of $C$. granarius (Figure $6)$.

The tibiae of the pedipalps present acute denticles in the fossil specimen, as in Cosmobunus granarius. The coxal denticles have a distribution in marginal rows (anterior and posterior), and are slightly trilobate. For the coxal denticles, only simple and trilobate denticles have been described, but there is variation in their relative development among species and even within the same row (see Prieto and Fernández, 2007).

The fossil specimen shows characters of both Leiobunum and Cosmobunus, but the characters typical of the latter have a greater taxonomic significance. The tarsal claws of the pedipalps, the dark lateral coloration with a clear central band, and the granular cuticle that covers the whole body are fea- 

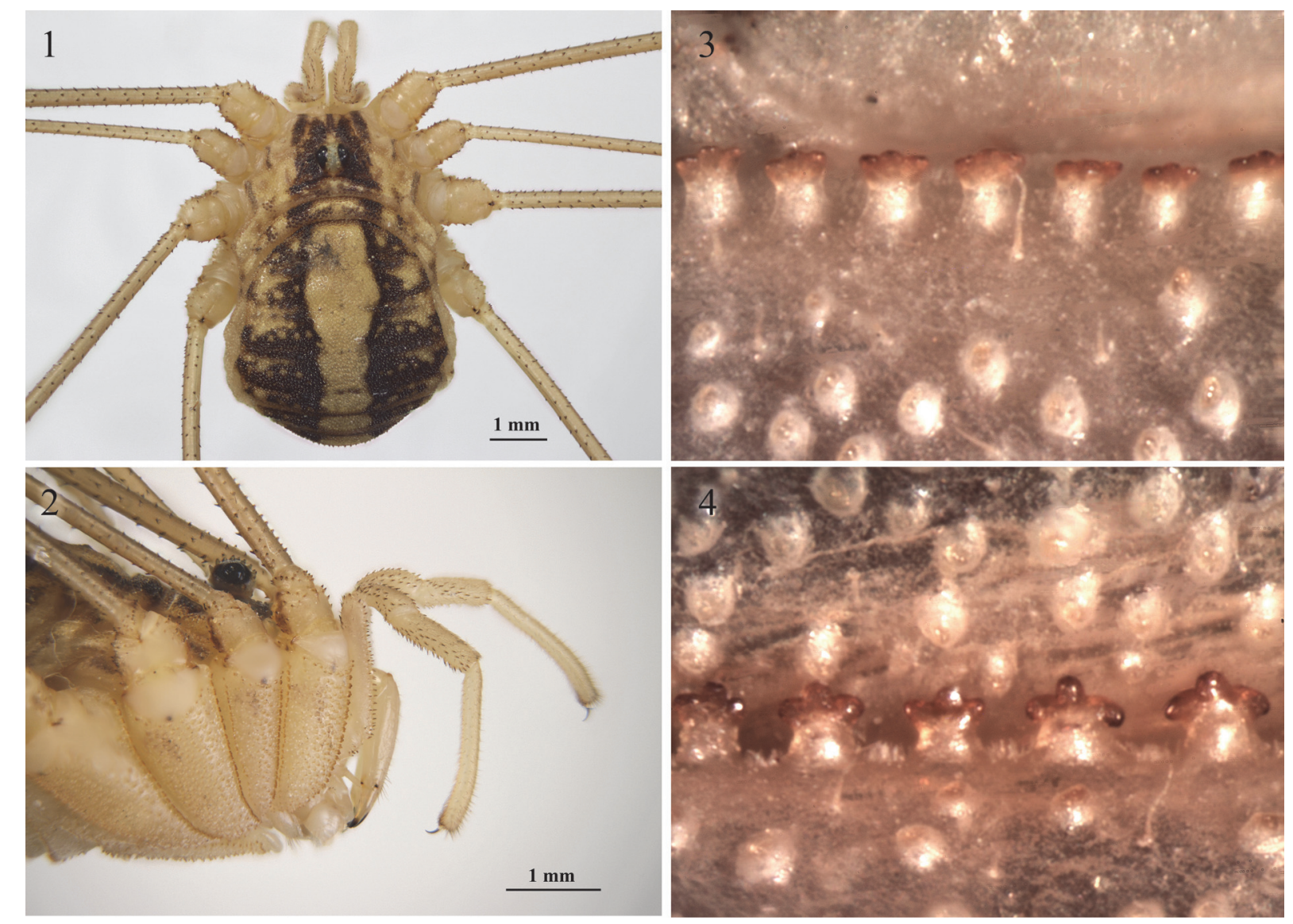

FIGURE 6. Photographs and microphotographs of extant Cosmobonus granarius for comparison. 1-2, Photographs of the body in dorsal and lateral views. Note the coxal denticles (images electronically made with consecutive pictures taken at successive focal planes). 3-4, Photomicrographs of two rows of trilobate coxal denticles in coxa I (3) and coxa IV (4).

tures unique to Cosmobunus within Sclerosomatidae. The smooth ocularium and the similar thickness of all femora distinguish the fossil specimen from the extant species Cosmobunus granarius indicating it is a new species.

The current geographical distribution of Cosmobunus granarius ranges from Barcelona to Algarve along the Iberian Mediterranean coast, plus inner Andalusia and southern regions of Extremadura and Castilla-La Mancha (Rambla, 1970; unpublished records), reaching as far north as Madrid. Interestingly, Rubielos de Mora is close to the boundary of this current distribution.

Paleobiology. The analogous extant species Cosmobunus granarius is lapidicole, active at dawn. It abounds on walls and tree trunks, and also on the ground, seeking for prey (spiders, mites, dipterans and isopods) (Rambla, 1970). During the day, the individuals of this species rest in dark places such as tree holes, caves, tunnels and under bridges.
They usually come together in compact and massive aggregations, taking the aspect of a bunch of roots. Solitary individuals rest in a distinctive manner on walls. Its life cycle is annual, with birth in early spring, growth until summer, maturation, copula and oviposition in late summer, and death in autumn, thus being stenochronous univoltine (Belozerov, 2012), at least in non-arid regions such as Catalonia. Such a life cycle can be modified in caves, where Rambla (1970) reported the presence of egg batches, young nymphs, and coexisting nymphs and adults. The egg batches have 1678 eggs (commonly 35-50), with average egg size of $1.14-1.25 \mathrm{~mm}$; eggs are laid into the ground, then covered by vegetal debris.

\section{WORLD FOSSIL RECORD OF HARVESTMEN}

Despite the extant abundance and biodiversity of the order and its ancient evolutionary history (Dunlop et al., 2013; Garwood et al., 2014), Opil- 


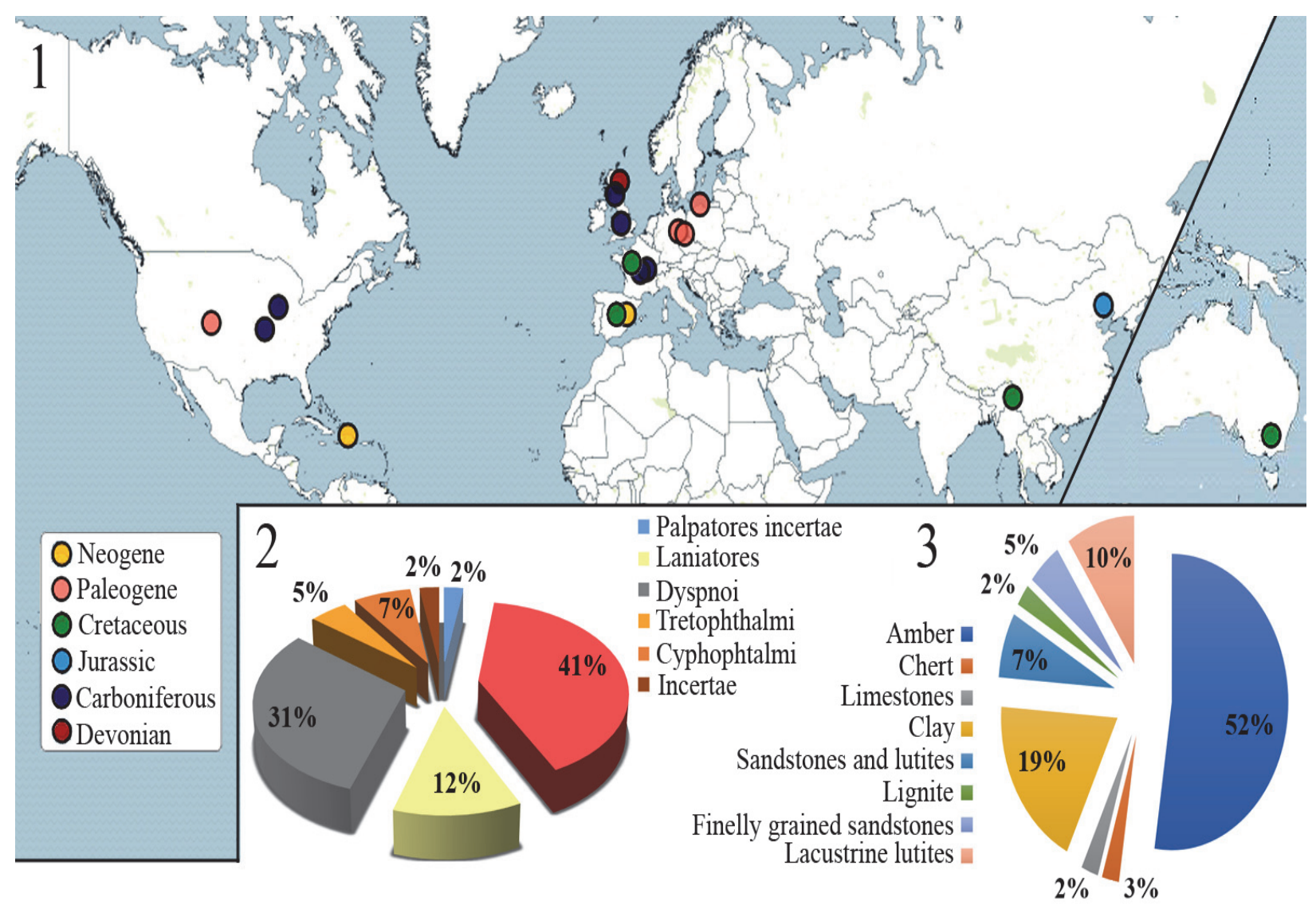

FIGURE 7. Fossil record of Opiliones. 1, Distribution of the paleontological localities that have yielded harvestmen species (plus the Opiliones indet. from Koonwarra Fossil Beds, Bezonnais or Anjou amber, and Las Hoyas). 2, Percentage of fossil species grouped in suborders. 3, Percentage diagram of the diverse types of fossilization. Primary source: Dunlop et al. (2018).

iones is only represented by 42 fossil species from 15 localities (Figure 7.1; Appendix). The scarcity of their fossil record is quite remarkable among most other arthropod orders. The bias in the fossil record of harvestmen can be explained as a combination of its low degree of potential fossilization and the generally cryptic biology of the extant members of the group.

The oldest record of Opiliones is Devonian in age (Pragian-Emsian, 410-393 million years old) (Figure 7; Appendix). This record agrees with the estimation of its origin by Garwood et al. (2014) and Sharma and Giribet (2014) by using a LN clock model. These authors also estimated the radiations of the crown groups for Opiliones during the Silurian and Devonian, but there is no fossil evidence for it. All suborders of Opiliones are considered to have originated during the Carboniferous (Garwood et al., 2014). There is a bias in their fossil record during the Permian and the Triassic, in accord with a similar bias in nearly all terrestrial arthropod groups. Three harvestmen species are known from the Jurassic and three from the Cretaceous. The richest period in fossil Opiliones is the Paleogene, specifically by preservation in Baltic and Bitterfeld amber deposits, middle Eocene in age (Lutetian, ca. 43 million years), showing exceptional preservation. Baltic and Bitterfeld ambers have been considered coeval (Grimaldi and Engel, 2005), but there is no consensus on this matter. These ambers differ consistently in their geochemical properties, which could be caused by differences in the depositional processes; the co-occurrence of several taxa seems to indicate the same age for the production of the resins (Wolfe et al., 2016). The youngest fossil record of harvestmen is from the Neogene (Burdigalian, ca. 18 million years).

Regarding the type of preservation of their fossil record, there is a clear prevalence of preservation in amber (Figure 7.3; Appendix). The noticeable difference in percentage for each type of 
fossilization could have taphonomic and paleoecologic causes. Amber originated in forested terrestrial environments, but the other types of fossilization of Opiliones correspond to aquatic sedimentary environments. In the case of Opiliones, their easy disarticulation and their low sclerotization limited the fossilization to KonservatLagerstätten.

In addition to the 15 outcrops that yielded fossil species of Opiliones (Figure 7; Appendix) (see also Dunlop et al., 2018), there are three additional Cretaceous outcrops that yielded indeterminate specimens: Koonwarra Fossil Beds in Australia, Bezonnais outcrop (Anjou amber) in France, and Las Hoyas in Spain. Except to for Koonwarra, all are in the Northern Hemisphere; Europe is the richest region with Opiliones-yielding outcrops. This circumstance is most likely a consequence of a sampling bias linked to a research bias, although confirmation requires a detailed study of the paleogeographical history of the group.

\section{CONCLUSIONS}

The specimens described in this study are the first Opiliones reported from the Spanish fossil record. They expand the ordinal-level taxonomic lists for the Konservat-Lagerstätte of Las Hoyas (Cretaceous) and Rubielos de Mora (Miocene). The special conditions necessary for the preservation of the delicate Opiliones and their condition as strictly terrestrial arthropods that live in cryptic environments are proposed to be the causes for the biases and scarcity of the fossil record of the group. This is consistent with the fact that their larger and better-preserved record is as bioinclusions in amber. It is interesting to note that the most diverse suborder of Opiliones in Recent biotas (Eupnoi) is the most represented in their fossil record as well. The fossil record of Opiliones is so scarce that we seem far from getting a comprehensible view on the evolutionary history of the group.

\section{ACKNOWLEDGMENTS}

We are grateful to the Museo de Paleontología de Castilla-La Mancha (MUPA) and the Museo de Ciencias Naturales de Valencia for permission to study the specimens. We wish to thank the two anonymous referees for their constructive comments and the Style Editor for his help.

\section{REFERENCES}

Anadón, P., Peñalver, E., and Alcalá, L. 2003. Exceptional fossil sites in Neogene basins of the central Iberian Chain (Teruel and Rubielos de Mora basins). Congress Field Trip Guide. EPAWorkshop 2003. Exceptional Preservation. Teruel:123-169.

Banks, N. 1893. The Phalanginae of the United States. The Canadian Entomologist, 25(8):205211. https://doi.org/10.4039/ent25205-8

Banks, N. 1900. New genera and species of American Phalangida. Journal of the New York Entomological Society, 8(3):199-201.

Banks, N. 1901. Synopses of North-American Invertebrates. XVI. The Phalangida. American Naturalist, 35:669-679. https://doi.org/10.1086/277984

Belozerov, V.N. 2012. Dormant stages and their participation in adjustment and regulation of life cycles of harvestmen (Arachnida, Opiliones). Entomological Review, 92(6):688-713. https:// doi.org/10.1134/s0013873812060073

Briggs, D.E.G., Gupta, N.S., and Cambra-Moo, Ó. 2016. Molecular preservation, p. 216-219. In Poyato-Ariza, F.J. and Buscalioni, A.D. (eds.), Las Hoyas: A Cretaceous Wetland. Verlag Dr. Friedrich Pfeil, Munich.

Buscalioni, A.D., Poyato-Ariza, F.J., Marugán-Lobón, J., Fregenal-Martínez, M., Sanisidro, Ó., Navalón, G., and de Miguel, C. 2016. The wetland of Las Hoyas, p. 238-253. In Poyato-Ariza, F.J. and Buscalioni, A.D. (eds.), Las Hoyas: A Cretaceous Wetland. Verlag Dr. Friedrich Pfeil, Munich.

Cockerell, T.D.A. 1907. Some fossil arthropods from Florissant, Colorado. Bulletin of the American Museum of Natural History, 23:605-616.

Cokendolpher, J.C. 1985. Revision of the harvestman genus Leptobunus and dismantlement of the Leptobunidae (Arachnida: Opiliones: Palpatores). Journal of the New York Entomological Society, 92(4) [1984]:371-402. 
Cokendolpher, J.C. 1987. A new species of fossil Pellobunus from Dominican Republic amber (Arachnida: Opiliones: Phalangodidae). Caribbean Journal of Science, 22:205-211.

Cokendolpher, J.C. and Poinar Jr., G.O. 1992. Tertiary harvestmen from Dominican Republic amber (Arachnida: Opiliones: Phalangodidae). Bulletin of the British Arachnological Society, 9:53-56.

Cokendolpher, J.C. and Poinar Jr., G.O. 1998. A new fossil harvestman from Dominican Republic amber (Opiliones, Samoidae, Hummelinckiolus). Journal of Arachnology, 26:9-13.

Delclòs, X. and Soriano, C. 2016. Insecta, p. 70-93. In Poyato-Ariza, F.J. and Buscalioni, A.D. (eds.), Las Hoyas: A Cretaceous Wetland. Verlag Dr. Friedrich Pfeil, Munich.

Dunlop, J.A. 2004. A spiny harvestman (Archnida: Opiliones) from the Upper Carboniferous of Missouri, USA, p. 67-74. In Logunov, D.V. and Penney, D. (eds.), European Arachnology 2003, Arthropoda Selecta, Special Issue n. 1, KMK Scientific Press, Moscow.

Dunlop, J.A. 2006. Baltic amber harvestman types (Arachnida: Opiliones: Eupnoi and Dyspnoi). Fossil Record, 9(2):167-182. https://doi.org/10.1002/mmng.200600006

Dunlop, J.A. and Anderson, L.I. 2005. A fossil harvestman (Arachnida, Opiliones) from the Mississippian of East Kirkton, Scotland. Journal of Arachnological Society, 33(2):482-489. https://doi.org/10.1636/04-79.1

Dunlop, J.A., Anderson, L.I., Kerp, H., and Hass, H. 2004. A harvestman (Arachnida: Opiliones) from the Early Devonian Rhynie cherts, Aberdeenshire, Scotland. Transactions of the Royal Society of Edinburgh: Earth Sciences, 94(4):341-354. https://doi.org/10.1017/ S0263593300000730

Dunlop, J.A., Bartel, C. and Mitov, P.G. 2012. An enigmatic spiny harvestman from Baltic amber. Fossil Record, 15(2):91-101. https://doi.org/10.1002/mmng.201200007

Dunlop, J.A. and Giribet, G. 2003. The first fossil cyphophthalmid (Arachnida, Opiliones) from Bitterfeld amber, Germany. The Journal of Arachnology, 31(3):371-378. https://doi.org/ 10.1636/h03-03

Dunlop, J.A. and Mammitzsch, L. 2010. A new genus and species of harvestman from Baltic amber. Paleodiversity, 3:23-32.

Dunlop, J.A. and Mitov, P.G. 2009. Fossil harvestmen (Arachnida, Opiliones) from Bitterfeld amber. ZooKeys, 16:347-375. https://doi.org/10.3897/zookeys.16.224

Dunlop, J.A. and Mitov, P.G. 2011. The first fossil cyphopthalmid harvestman from Baltic amber. Arachnologische Mitteilungen, 40:47-54. https://doi.org/10.5431/aramit4006

Dunlop, J.A., Penney, D., and Jekel, D. 2018. A summary list of fossil spiders and their relatives. World Spider Catalog. Natural History Museum Bern, version 19.5. https://doi.org/10.5431/ aramit4006

Dunlop, J.A., Scholtz, G., and Selden, P.A. 2013. Water-to-land transitions, p. 417-439. In Minelli, A., Boxshall, G., and Fusco, G. (eds.), Arthropod Biology and Evolution. Springer Berlin Heidelberg, Berlin.

Engel, M.S. and Peñalver, E. 2006. A Miocene halictine bee from Rubielos de Mora Basin, Spain (Hymenoptera: Halictidae). American Museum Novitates, 3503: 10 pp. https://doi.org/ 10.1206/0003-0082(2006)503[0001:amhbfr]2.0.co;2

Fernández, R., Sharma, P.P., Tourinho, A.L., and Giribet, G. 2017. The Opiliones tree of life: shedding light on harvestmen relationships through transcriptomics. Proceedings of the Royal Society B, 284:20162340. https://doi.org/10.1101/077594

Fregenal-Martínez, M. and Meléndez, N. 2016. Environmental reconstruction: a historical review, p. 14-28. In Poyato-Ariza, F.J. and Buscalioni, A.D. (eds.), Las Hoyas: A Cretaceous Wetland. Verlag Dr. Friedrich Pfeil, Munich.

Garassino, A. 2016. Decapoda, p. 98-102. In Poyato-Ariza, F.J. and Buscalioni, A.D. (eds.), Las Hoyas: A Cretaceous Wetland. Verlag Dr. Friedrich Pfeil, Munich.

Garwood, R.J., Dunlop, J.A., Giribet, G., and Sutton, M.D. 2011. Anatomically modern Carboniferous harvestmen demonstrate early cladogenesis and stasis in Opiliones. Nature Communications, 2(444):1-7. https://doi.org/10.1038/ncomms1458

Garwood, R.J., Sharma, P.P., Dunlop, J.A., and Giribet, G. 2014. A Paleozoic stem group to mite harvestmen revealed through integration of phylogenetics and development. Current Biology, 24:1017-1023. https://doi.org/10.1016/j.cub.2014.03.039

Giribet, G. and Dunlop, J.A. 2005. First identifiable Mesozoic harvestman (Opiliones: Dyspnoi) from Cretaceous Burmese amber. Proceedings of the Royal Society B, 272:1007-1013. https://doi.org/10.1098/rspb.2005.3063 
Giribet, G. and Sharma, P.P. 2015. Evolutionary biology of harvestmen (Arachnida, Opiliones). Annual Review of Entomology, 60(1):157-175. https://doi.org/10.1146/annurev-ento-010814021028

Giribet, G., Tourinho, A.L., Shih, C., and Ren, D. 2012. An exquisitely preserved harvestman (Arthropoda Arachnida, Opiliones) from the Middle Jurassic of China. Organisms, Diversity \& Evolution, 2(1):51-56. https://doi.org/10.1007/s13127-011-0067-x

Grimaldi, D.A. and Engel, M.S. 2005. Evolution of the Insects. Cambridge University Press: 755 pp. New York.

Hansen, H.J. and Sørensen, W. 1904. On Two Orders of Arachnida: Opiliones, Especially the Suborder Cyphophthalmi, and Ricinulei, Namely the Family Cryptostemmatoidae. Cambridge University Press: 174 pp, pls. I-VII. Cambridge. https://doi.org/10.5962/ bhl.title.13898

Haupt, H. 1956. Beitrag zu Kenntnis der eözanen Arthropodenfauna des Geiselthals. Nova Acta Leopoldina n.s., 128:1-90.

Hedin M., Tsurusaki, N., Macías-Ordóñez, R., and Shultz, J.W. 2012. Molecular systematics of sclerosomatid harvestmen (Opiliones, Phalangioidea, Sclerosomatidae): geography is better than taxonomy in predicting phylogeny. Molecular Phylogenetics and Evolution, 62(1):22-236. https://doi.org/10.1016/j.ympev.2011.09.017

Huang, D., Selden, P.A., and Dunlop, J.A. 2009. Harvestmen (Arachnida: Opiliones) from the Middle Jurassic of China. Naturwissenschaften, 96(8):95-962. https://doi.org/10.1007/ s00114-009-0556-3

Jaume, D., Pinardo-Moya, E., and Boxshall, G.A. 2016. Spelaeogriphacea, p. 94-97. In PoyatoAriza, F.J. and Buscalioni, A.D. (eds.), Las Hoyas: A Cretaceous Wetland. Verlag Dr. Friedrich Pfeil, Munich.

Koch, C.L. 1839. Übersicht des Arachnidensystems. Zweites Heft. C.H. Zeh, Nürnberg: 38 pp, 6 pls. Nürnberg.

Koch, C.L. and Berendt, G.C. 1854. Die im Bernstein befindlichen Myriapoden, Crustaceen, Arachniden und Apteren der Vorwelt, p. 1-124. In Berendt, G.C. (ed.), Die in Bernstein befindlichen organischen Reste der Vorwelt gesammelt in verbindung mit mehreren bearbeitetet und herausgegeben, In Commission der Nicolaischen Buchhandlung, Berlin.

Kury, A.B. 2017. Classification of Opiliones. Museu Nacional/UFRJ website. http:// www.museunacional.ufr.br/mndi/Aracnologia/opiliones.html

Lamarck, J.B. 1801 Système des Animaux sans vertèbres, ou Tableau général des classes, des ordres et des genres de ces animaux. Déterville: 432 pp, VIII pls. Paris.

Latreille, P.A. 1798 Mémoire pour servir de suite à l'histoire des insectes connus sous le nom de Faucheurs. Phalangium. L. Bulletin des Sciences par la Société Philomathique, 1(15):113115.

Lucas, P.H. 1846. Deuxième classe. Arachnides, p. 89-320. In Exploration scientifique de l'Algérie pendant les années 1840, 1841, 1842. Sciences physiques. Zoologie III ("1849"). Imprimerie royale, Paris

Martens, J. 1987. Opiliones aus dem Nepal-Himalaya. VI. Gagrellinae (Arachnida: Phalangiidae). Courier Forschungsinstitut Senckenberg, Frankfurt am Main, 93:87-202.

Menge, A. 1854. Footnotes. In Berendt, G.C. (ed.), Die in Bernstein befindlichen organischen Reste der Vorwelt gesammelt in verbindung mit mehreren bearbeitetet und herausgegeben, In Commission der Nicolaischen Buchhandlung, Berlin.

Mitov, P.G., Dunlop, J.A., and Penney, D. 2015. A new species of Lacinius in amber (Arachnida: Opiliones). Fossil Record, 18(1):37-42. https://doi.org/10.5194/fr-18-37-2015

Montoya, P., Peñalver, E., Ruiz-Sánchez, F.J., Santisteban, C., Alcalá, L., Belinchón, M., and Lacomba, J.I. 1996. Los yacimientos paleontológicos de la cuenca terciaria continental de Rubielos de Mora (Aragón). Revista Española de Paleontología, nº extra.:215-224.

Peñalver, E. 1998. Estudio tafonómico y paleoecológico de los insectos del Mioceno de Rubielos de Mora (Teruel). Instituto de Estudios Turolenses Ed.: 179 pp. Teruel.

Peñalver, E. 2002. Los insectos dípteros del Mioceno del Este de la Península Ibérica; Rubielos de Mora, Ribesalbes y Bicorp. Tafonomía y sistemática. Tesis Doctoral. Universitat de València. Valencia.

Peñalver, E. 2007. 4. Insect paleofauna of Rubielos de Mora Basin (Lower Miocene, northeast Spain). Delclòs X. and Soriano C. Mesozoic and Cenozoic Spanish Insect Localities. Field Trip Guide Book. International Palaeoentomological Society. Diputación de Álava. 
Peñalver, E. and Engel, M. 2006. Two wasp families rare in the fossil record (Hymenoptera): Perilampidae and Megaspilidae from the Miocene of Spain. American Museum Novitates, 3540:12 pp. https://doi.org/10.1206/0003-0082(2006)3540[1:twfrit]2.0.co;2

Peñalver, E. and Seilacher, A. 1995. Rubielos de Mora- Eine untermiozäne Fossil-Lagerstätte. Fossilien, 1995 (4):211-216.

Petrunkevitch, A.I. 1913. A monograph of the terrestrial Palaeozoic Arachnida of North America. Transactions of the Connecticut Academy of Arts and Sciences, 18:1-137.

Petrunkevitch, A.I. 1922. Tertiary spiders and opilionids of North America. Transactions of the Connecticut Academy of Arts and Sciences, 25:211-279.

Petrunkevitch, A.I. 1949. A study of Palaeozoic Arachnida. Transactions of the Connecticut Academy of Arts and Sciences, 37:69-315.

Pinto-da-Rocha, R. and Giribet, G. 2007. Taxonomy, p. 88-247. In Pinto-da-Rocha, R., Machado, G. and Giribet, G. (eds.), Harvestmen. The Biology of Opiliones. Cambridge: Harvard Press.

Pocock, R.I. 1911. A monograph of the terrestrial Carboniferous Arachnida of Great Britain. Monographs of the Palaeontographical Society, 64:1-84. https://doi.org/10.5962/ bhl.title.46330

Poinar, G. 2008. Palaeosiro burmanicum gen., n. sp., a fossil Cyphophthalmi (Arachnida: Opiliones: Sironidae) in Early Cretaceous Burmese amber, p. 267-274. In Makarov, S.E. and Dimitriević, R.N. (eds.), Advances in Arachnology and Developmental Biology. Papers dedicated to Prof. Dr. Božidar Ćurčić. Monographs, 12, Universität Wien, Vienna.

Poyato-Ariza, F.J. and Buscalioni, A.D. 2016. Exceptional preservation, p. 229-231. In PoyatoAriza, F.J. and Buscalioni, A.D. (eds.), Las Hoyas: A Cretaceous Wetland. Verlag Dr. Friedrich Pfeil, Munich.

Prieto, C.E. and Fernández, J. 2007. El género Leiobunum C.L. Koch, 1839 (Opiliones: Eupnoi. Sclerosomatidae) en la Península lbérica y el norte de África con la descripción de tres nuevas especies. Revista Ibérica de Aracnalogía, 14:135-171.

Rambla, M. 1959. Contribuciones al Estudio de los Opiliones de la fauna Ibérica. Opiliones de la Sierra de Guadarrama. Publicaciones del Instituto de Biología Aplicada, 29:59-110.

Rambla, M. 1970. Contribución al estudio de los Opiliones de la Fauna Ibérica. La especie Cosmobunus granarius (Lucas 1847) en la Península Ibérica y Norte de África. Publicaciones del Instituto de Biologia Aplicada, 48:81-105.

Roewer, C.F. 1910. Revision der Opiliones Plagiostethi (= Opiliones Palpatores). I. Teil: Familie der Phalangiidae. (Subfamilien: Gagrellini, Liobunini, Leptobunini). Abhandlungen aus dem Gebiete der Naturwissenschaften, herausgegeben vom Naturwissenschaftlichen Verein in Hamburg, 19(4):1-294.

Roewer, C.F. 1923. Die Weberknechte der Erde. Systematische Bearbeitung der bisher bekannten Opiliones. Gustav Fischer: 1116 pp. Jena.

Rodríguez-Lázaro, J. 2016. Ostracoda, p. 89-93. In Poyato-Ariza, F.J. and Buscalioni, A.D. (eds.), Las Hoyas: A Cretaceous Wetland. Verlag Dr. Friedrich Pfeil, Munich.

Ruppert, E.E., Fox, R.S., and Barnes, R.D. 2004. Chelicerata. Pg. 554-604. In Ruppert E.E., Fox, R.S., and Barnes, R.D. (ed). Invertebrate Zoology: A Functional Evolutionary Approach $\left(7^{\text {th }}\right)$. Belmont, C.A.: Thomson-Brooks/Cole.

Scudder, S.H. 1890. Illustrations of the Carboniferous Arachnida of North America, of the orders Anthracomarti and Pedipalpi. Memoirs of the Boston Society of Natural History, 4:443-456.

Selden, P.A. 2016. Arachnida, p. 64-67. In Poyato-Ariza, F.J. and Buscalioni, A.D. (eds.), Las Hoyas: A Cretaceous Wetland. Verlag Dr. Friedrich Pfeil, Munich.

Selden, P.A. and Shear, W.A. 2016. Diplopoda, p. 68-69. In Poyato-Ariza, F.J. and Buscalioni, A.D. (eds.), Las Hoyas: A Cretaceous Wetland. Verlag Dr. Friedrich Pfeil, Munich.

Selden, P.A., Dunlop, J.A., Giribet, G., Zhang, W., and Ren, D. 2016. The oldest armoured harvestman (Arachnida: Opiliones: Laniatores), from Upper Cretaceous Myanmar amber. Cretaceous Research, 65:206-212. https://doi.org/10.1016/j.cretres.2016.05.004

Sharma, P.P. and Giribet, G. 2014. A revised dated phylogeny of the arachnid order Opiliones. Frontiers in Genetics, 5:1-13. https://doi.org/10.3389/fgene.2014.00255

Shultz, J.W. and Pinto-da-Rocha, R. 2007. Morphology and functional anatomy, p 14-61. In Pinto-da-Rocha, R., Machado, G., and Giribet, G. (eds.), Harvestmen. The Biology of Opiliones. Cambridge: Harvard Press.

Simon, E. 1879. Les Arachnides de France. Tome 7. Contenant les ordres des Chernetes, Scorpiones et Opiliones. Librairie Encyclopédique de Roret: 332 pp., pl. 17-24. Paris. 
Sundevall, K.J. 1833. Conspectus Arachnidum. C.F.Berling: 39 pp. London.

Thevenin, M.A. 1901. Sur la découverte d'Arachnides dans le terrain houiller de Commentry. Bulletin de la Société Géologique de France, 4e Série, 1:605-611.

Wegierek, P. and Peñalver, E. 2002. Fossil representatives of the family Greenideidae (Hemiptera, Aphidoidea) from the Miocene of Europe. Geobios, 35:745-757. https://doi.org/ 10.1016/s0016-6995(02)00086-4

Wolfe, A.P., McKellar, R.C., Tappert, R., Sodhi, R.N.S., and Muehlenbachs, K. 2016. Bitterfeld amber is not Baltic amber: Three geochemical tests and further constraints on the botanical affinities of succinate. Review of Palaeobotany and Palynology, 225:21-32. 


\section{APPENDIX}

List of valid fossil species of Opiliones, from oldest to most recent (primary source: Dunlop et al., 2018). (1)= Tetrophthalmi; (2)= Eupnoi; (3)= Dyspnoi; (4)= Laniatores; (5)= Cyphophthalmi; Bar= Bartonian; Bas= Bashkirian; Bur= Burdigalian; $\mathrm{C}=$ Carboniferous; Cal= Callovian; Cen= Cenomanian; D= Devonian; Ems= Emsian; Gzh= Gzhelian; J= Jurassic; K= Cretaceous; Lut= Lutetian; Mos= Moscovian; $\mathrm{Ne}=$ Neogene; $\mathrm{Pa}=$ Paleogene; Pra= Pragian; Vis= Visean; Ypr= Ypresian; *= Fossil genus.

\begin{tabular}{|c|c|c|c|c|c|}
\hline Species & $\begin{array}{l}\text { Family/ } \\
\text { (Suborder) }\end{array}$ & System & Stage & Outcrop/Region & $\begin{array}{c}\text { Type of } \\
\text { fossilization }\end{array}$ \\
\hline Eophalangium sheari Dunlop et al., 2004* & Not described (1) & $\mathrm{D}$ & Pra-Ems & Rhynie & Chert \\
\hline $\begin{array}{l}\text { Brigantibunum listoni Dunlop and Anderson, } \\
2005^{\star}\end{array}$ & Plesion (2) & $\mathrm{C}$ & Vis & East Kirkton & Limestones \\
\hline $\begin{array}{l}\text { Echinopustulatus samuelnelsoni Dunlop, } \\
2004^{*}\end{array}$ & Family indet. (3) & C & Mos & Missouri & Clay \\
\hline Archaeometa nephilina Pocock, 1911 & $\begin{array}{l}\text { Archaeometidae (2) } \\
\text { or (4) }\end{array}$ & $\mathrm{C}$ & Mos & Measures of Coseley & Clay \\
\hline Arachnometa tuberculata Petrunkevitch, 1949 & Family indet, (?) & $\mathrm{C}$ & Mos & Measures of Coseley & Clay \\
\hline Hastocularis argus Garwood et al., 2014 & Not described (1) & $\mathrm{C}$ & Bas & Montceau-les-Mines & Clay \\
\hline Eotrogulus fayoli Thevenin, $1901^{*}$ & Eotrogulidae (3) & C & Bas & Commentry & $\begin{array}{l}\text { Finely grained } \\
\text { sandstones }\end{array}$ \\
\hline Nemastomoides elaveris Thevenin, $1901^{*}$ & Nemastomoidae (3) & C & Bas & Commentry & $\begin{array}{l}\text { Finely grained } \\
\text { sandstones }\end{array}$ \\
\hline Ameticos scolos Garwood et al., 2011 & Family indet. (3) & $\mathrm{C}$ & Bas & Montceau-les-Mines & Clay \\
\hline Macrogyion cronus Garwood et al., 2011 & Plesion (2) & $\mathrm{C}$ & Bas & Montceau-les-Mines & Clay \\
\hline Kustarachne tenuipes Scudder, $1890^{*}$ & Plesion (2) & C & Gzh & Mazon Creek & Clay \\
\hline $\begin{array}{l}\text { Nemastomoides longipes (Petrunkevitch, } \\
\text { 1913) }\end{array}$ & Nemastomoididae (3) & C & Gzh & Mazon Creek & Clay \\
\hline $\begin{array}{l}\text { Mesobunus martensi Huang, Selden and } \\
\text { Dunlop, 2009*}\end{array}$ & Sclerosomatidae (2) & $\mathrm{J}$ & Cal & Daohugou & $\begin{array}{l}\text { Sandstones and } \\
\text { lutites }\end{array}$ \\
\hline $\begin{array}{l}\text { Daohugopilio sheari Huang, Selden and } \\
\text { Dunlop, 2009*}\end{array}$ & Family indet. (2) & $\mathrm{J}$ & Cal & Daohugou & $\begin{array}{l}\text { Sandstones and } \\
\text { lutites }\end{array}$ \\
\hline Mesobunus dunlopi Giribet et al., 2012 & $\begin{array}{l}\text { Sclerosomatididae } \\
\text { (2) }\end{array}$ & $\mathrm{J}$ & Cal & Daohugou & $\begin{array}{l}\text { Sandstones and } \\
\text { lutites }\end{array}$ \\
\hline Palaeosiro burmanicum Poinar, 2008 & Stylocellidae (5) & K & Cen & Myanmar & Amber \\
\hline $\begin{array}{l}\text { Halitherses grimaldii Giribet and Dunlop, } \\
\text { 2005* }\end{array}$ & Halithersidae (3) & $\mathrm{K}$ & Cen & Myanmar & Amber \\
\hline Petrobunoides sharmai Selden et al., 2016 & Epedanidae (4) & $\mathrm{K}$ & Cen & Myanmar & Amber \\
\hline Trogulus longipes Haupt, 1956 & Trogulidae (3) & $\mathrm{Pa}$ & Lut-Ypr & Geiseltal & Lignite \\
\hline Siro platypedibus Dunlop and Giribet, 2003 & Sironidae (5) & $\mathrm{Pa}$ & Lut & Bitterfeld & Amber \\
\hline Siro balticus Dunlop and Mitov, 2011 & Sironidae (5) & $\mathrm{Pa}$ & Lut & Baltic Region & Amber \\
\hline Caddo dentipalpus (Koch and Berendt, 1854) & Caddidae (2) & $\mathrm{Pa}$ & Lut & Baltic Region & Amber \\
\hline $\begin{array}{l}\text { Dicranopalpus ramiger (Koch and Berendt, } \\
\text { 1854) }\end{array}$ & Phalangiidae (2) & $\mathrm{Pa}$ & Lut & Baltic Region & Amber \\
\hline Opilio ovalis Koch and Berendt, 1854 & ?Phalangiidae (2) & $\mathrm{Pa}$ & Lut & Baltic Region & Amber \\
\hline Leiobunum longipes Menge, 1854 & Sclerosomatidae (2) & $\mathrm{Pa}$ & Lut & Baltic Region & Amber \\
\hline Sabacon claviger (Menge, 1854) & Sabaconidae (3) & $\mathrm{Pa}$ & Lut & Baltic Region & Amber \\
\hline $\begin{array}{l}\text { ?Histricostoma tuberculatum (Koch and } \\
\text { Berendt, 1854) }\end{array}$ & Nemastomatidae (3) & $\mathrm{Pa}$ & Lut & Baltic Region & Amber \\
\hline $\begin{array}{l}\text { ?Mitostoma denticulatum (Koch and Berendt, } \\
\text { 1854) }\end{array}$ & Nemastomatidae (3) & $\mathrm{Pa}$ & Lut & Baltic Region & Amber \\
\hline
\end{tabular}


PAlencia et Al.: NeW Fossil haRVEStMen

\begin{tabular}{|c|c|c|c|c|c|}
\hline Species & $\begin{array}{l}\text { Familyl } \\
\text { (Suborder) }\end{array}$ & System & Stage & Outcrop/Region & $\begin{array}{c}\text { Type of } \\
\text { fossilization }\end{array}$ \\
\hline $\begin{array}{l}\text { ?Nemastoma incertum Koch and Berendt, } \\
1854\end{array}$ & Nemastomatidae (3) & $\mathrm{Pa}$ & Lut & Baltic Region & Amber \\
\hline $\begin{array}{l}\text { Proholoscotolemon nemastomoides (Koch } \\
\text { and Berendt, 1854)* }\end{array}$ & Cladonychidae (4) & $\mathrm{Pa}$ & Lut & Baltic Region & Amber \\
\hline $\begin{array}{l}\text { Piankhi steineri Dunlop, Bartel and Mitov, } \\
2012^{*}\end{array}$ & Family indet. (3) & $\mathrm{Pa}$ & Lut & Baltic Region & Amber \\
\hline $\begin{array}{l}\text { Lacinius bizleyi Mitov, Dunlop and Penney, } \\
2015\end{array}$ & Phalangiidae (2) & $\mathrm{Pa}$ & Lut & Baltic Region & Amber \\
\hline Amilenus deltshevi Dunlop and Mitov, 2009 & Phalangiidae (2) & $\mathrm{Pa}$ & Lut & Bitterfeld & Amber \\
\hline Mitostoma gruberi Dunlop and Mitov, 2009 & Nemastomatidae (3) & $\mathrm{Pa}$ & Lut & Bitterfeld & Amber \\
\hline $\begin{array}{l}\text { Stephanobunus mitovi Dunlop and } \\
\text { Mammitzsh } 2010\end{array}$ & Phalangiidae (2) & $\mathrm{Pa}$ & Lut & Baltic Region & Amber \\
\hline $\begin{array}{l}\text { Petrunkevitchiana oculata (Petrunkevitch, } \\
\text { 1922)* }\end{array}$ & Family indet. (2) & $\mathrm{Pa}$ & Bar & Florissant & Lacustrine lutites \\
\hline Amauropilio atavus (Cockerell, 1907) & Sclerosomatidae (2) & $\mathrm{Pa}$ & Bar & Florissant & Lacustrine lutites \\
\hline Amauropilio lacoei (Petrunkevitch, 1922) & Sclerosomatidae (2) & $\mathrm{Pa}$ & Bar & Florissant & Lacustrine lutites \\
\hline $\begin{array}{l}\text { Philacarus hispaniolensis Cokendolpher and } \\
\text { Poinar, } 1992\end{array}$ & Family indet. (4) & $\mathrm{Ne}$ & Bur & Dominican Rep. & Amber \\
\hline $\begin{array}{l}\text { Hummelinckiolus silhavyi Cokendolpher and } \\
\text { Poinar, } 1998\end{array}$ & Samoidae (4) & $\mathrm{Ne}$ & Bur & Dominican Rep. & Amber \\
\hline Pellobunus proavus Cokendolpher, 1987 & Samoidae (4) & $\mathrm{Ne}$ & Bur & Dominican Rep. & Amber \\
\hline Cosmobunus sagani nov. sp. (this study) & Sclerosomatidae (2) & $\mathrm{Ne}$ & Bur & Rubielos de Mora & Lacustrine lutites \\
\hline
\end{tabular}

